\title{
Postglacial vegetation dynamics of western Tierra del Fuego ${ }^{\dagger}$
}

\author{
Sonia L Fontana ${ }^{1,2}$ and KD Bennett ${ }^{2,3}$
}

\section{Abstract}

The southern fringes of the South American landmass provide a rare opportunity to examine the development of moorland vegetation with sparse tree cover in a wet, cool temperate climate of the Southern Hemisphere. We present a record of changes in vegetation over the past I7,000 years, from a lake in extreme southern Chile (Isla Santa Inés, Magallanes region, $53^{\circ} 38.97 \mathrm{~S} ; 72^{\circ} 25.24 \mathrm{~W}$ ), where human influence on vegetation is negligible. The western archipelago of Tierra del Fuego remained treeless for most of the Lateglacial period; Lycopodium magellanicum, Gunnera magellanica and heath species dominated the vegetation. Nothofagus may have survived the last glacial maximum at the eastern edge of the Magellan glaciers from where it spread southwestwards and established in the region at around 10,500 cal. yr BP. Nothofagus antarctica was likely the earlier colonizing tree in the western islands, followed shortly after by Nothofagus betuloides. At 9000 cal. yr BP moorland communities expanded at the expense of Nothofagus woodland. Simultaneously, Nothofagus species shifted to dominance of the evergreen Nothofagus betuloides and the Magellanic rain forest established in the region. Rapid and drastic vegetation changes occurred at 5200 cal. yr BP, after the Mt Burney MB2 eruption, including the expansion and establishment of Pilgerodendron uviferum and the development of mixed Nothofagus-Pilgerodendron-Drimys woodland. Scattered populations of Nothofagus, as they occur today in westernmost Tierra del Fuego may be a good analogue for Nothofagus populations during the Lateglacial in eastern sites.
\end{abstract}

\section{Keywords}

Holocene, Lateglacial, Magellanic moorland, Nothofagus, pollen analysis, postglacial vegetation dynamics, Tierra del Fuego

Received I3 November 20II; revised manuscript accepted 22 February 2012

\section{Introduction}

During the last glacial period an extended ice cap expanded over the southern Andes of Patagonia and Tierra del Fuego (Coronato et al., 2004). At its maximum extent, the distribution and abundance of most plant taxa must have differed greatly from the present day. Some of the flora may have retreated eastwards of its present location, to the unglaciated areas of eastern Fuego-Patagonia and the continental shelf, exposed by glacioeustatic lowering of the sea level (Auer, 1958; Rabassa et al., 2005), while other species may have also survived cold stages on nunatak refugia within the ice cap. Postglacial pollen sequences show that most of the area covered by Nothofagus forests today was occupied by steppe and heath vegetation immediately following deglaciation (e.g. Heusser, 2003; Markgraf and Huber, 2010). The low values of Nothofagus pollen recorded throughout the Lateglacial suggest the survival of small tree populations in suitable habitats, widely distributed within the modern extent of forests, outside the glacier limit. The present pattern of forest distribution may thus have developed as a consequence of re-expansion of those relict populations (Markgraf and McGlone, 2005; Markgraf et al., 1995). Postglacial human populations seem to have been low-density coastal populations, subsisting primarily by hunting and gathering, with little or no impact on the inland mosaic of forest and heath communities (Borrero, 2008). The region thus provides an opportunity to examine how such a mosaic develops in a wet cool temperate climate in the absence of human agricultural and grazing impacts, in contrast to the situation in northwest Europe (Bennett et al., 1997).

The ice fields centred over Cordillera Darwin and adjacent mountains were the principal source for the glaciers in Tierra del Fuego. Large glaciers advanced along the Straits of Magellan and extended over the western islands towards the Pacific. Beyond the eastern slopes, numerous outlet glaciers flowed down into the plains along fjords and valleys to the Atlantic, covering most of the main Tierra del Fuego island (Coronato et al., 2004; Figure 1a). Following deglaciation significant vegetation changes took place over several millennia. Changes are usually attributed to external forcing factors, including climate change, volcanic eruption, fire, human activity and others. Additionally, vegetation has likely changed through its own internal dynamics (Bennett and Willis, 1995), including the spread of plants and colonization of new ground, competition for suitable habitats and succession. Moreover some species may still be increasing their distribution range and communities with no modern analogues have likely formed and disappeared.

The postglacial development of the Fuego-Patagonia flora has been the focus of numerous investigations. Von Post (1929) first studied pollen assemblages from Lago Fagnano in Tierra del Fuego, followed by the extensive work of Auer $(1933,1958)$, who established the essence of the vegetation history of Fuego-Patagonia. Auer's work is particularly impressive in detail and coverage over

\footnotetext{
'University of Göttingen, Germany

${ }^{2}$ Queen's University Belfast, UK

${ }^{3}$ Uppsala University, Sweden

† We dedicate this paper in appreciation to Professor Sara Ballent for her enthusiastic leadership, encouragement and support of many scientists and students over many years.
}

\section{Corresponding author:}

Sonia L Fontana, Department of Palynology and Climate Dynamics, Albrecht-von-Haller-Institute for Plant Sciences, University of Göttingen, Untere Karspüle 2, 37073 Göttingen, Germany. Email: sonia.fontana@biologie.uni-goettingen.de 


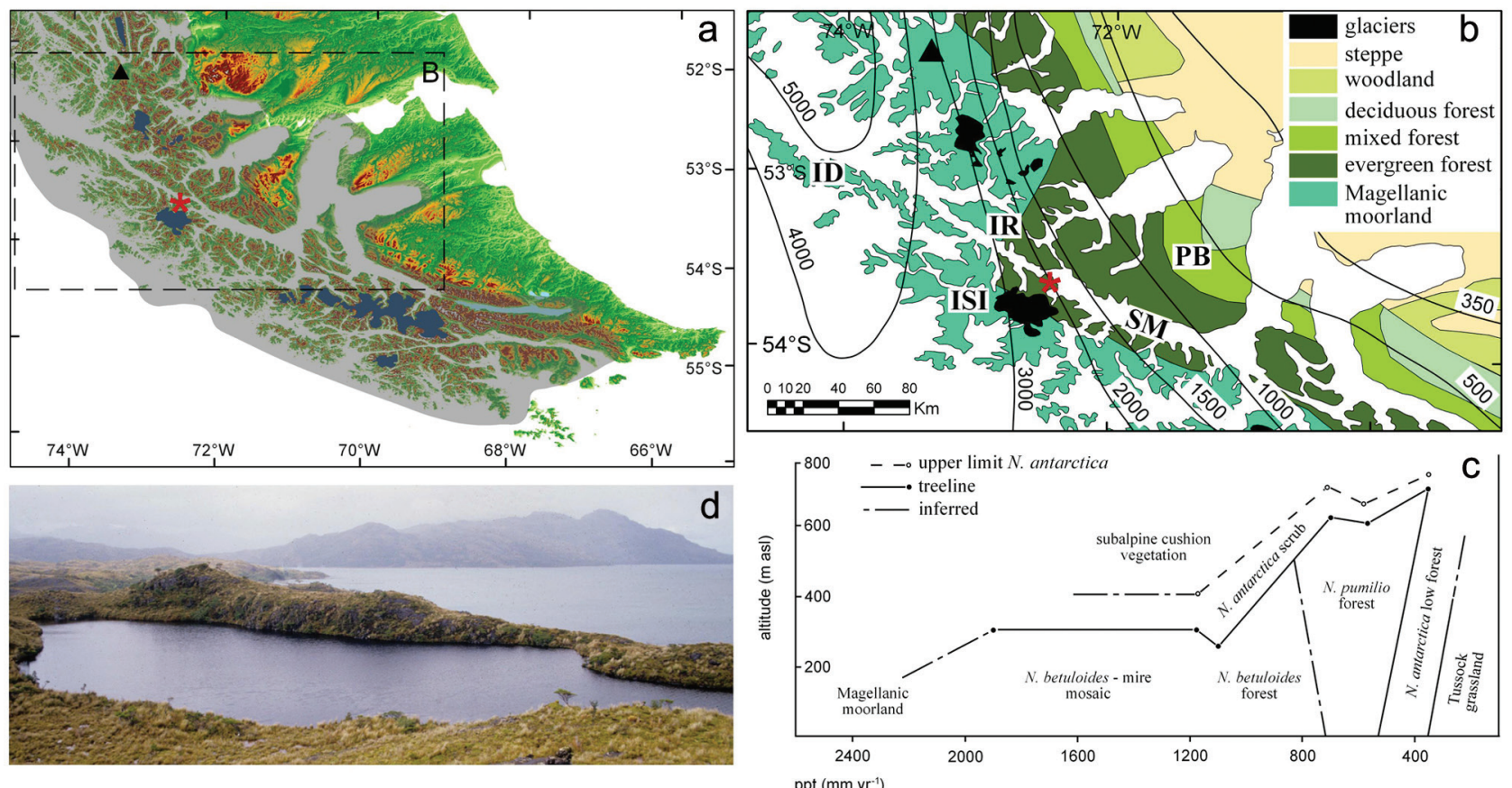

Figure I. (a) Map of southern Patagonia and Tierra del Fuego showing the maximum extent of ice during the last glacial period (light grey), present glaciers (black) (after Coronato et al., 2004), location of the studied site (asterisk) and Mount Burney (triangle). (b) Vegetation zones of the study area and mean annual precipitation $(\mathrm{mm})$. ID: Isla Desolación; ISI: Isla Santa Inés; IR: Isla Riesco; PB: Peninsula Brunswick; SM: Straits of Magellan. (c) Distribution of Nothofagus and surrounding vegetation around the Straits of Magellan and Tierra del Fuego (from McQueen, 1976). (d) Lake Ballena.

the large region, although lacking an absolute chronology. Work by Heusser (e.g. 1989, 1990, 1994, 1995, 1998, 2003) and Markgraf (e.g. 1980, 1983, 1993a, 2001) represent major research on the postglacial vegetational history and climate dynamics of the southern-most part of Patagonia and Tierra del Fuego. During the last decades, Borromei (1995), Borromei et al. (2007, 2010), FesqMartin et al. (2004), Mauquoy et al. (2004), McCulloch and Davies (2001), Pendall et al. (2001), Ponce et al. (2011), Recasens et al. (2011) and Wille et al. (2007) added important detail to the study of vegetation dynamics and landscape development of the region. The available palaeoecological archives are mainly concentrated along the eastern margin of the maximum ice extent, within the present distribution of Nothofagus forests. In contrast the vegetation history of the western archipelago, within the distributional limits of Nothofagus antarctica and Nothofagus betuloides, is still largely unknown. This investigation contributes to closing this gap in spatial cover and gives insight into the local vegetation dynamics at the western limit of tree distribution over a 17,000 yr period since deglaciation without the complication of significant human impacts.

This study presents results from a new palaeoecological record from the sediments of a small lake (Ballena) on Isla Santa Inés (Figure 1a, d) in order to: (1) investigate the development of plant communities in western Tierra del Fuego following the retreat of the Magellan glacier; (2) contribute to the understanding of postglacial vegetation dynamics, determining the relative role of internal processes (species interactions) and external forcing factors (climate, volcanic eruptions) controlling vegetation composition; and (3) document the presence and abundance of forest taxa with a strong emphasis on Nothofagus species in order to assess the direction, timing and pathways by which trees spread into western Tierra del Fuego.

Vascular plant nomenclature follows the database Flora del Conosur, Catálogo de las Plantas Vasculares published online by the Instituto de Botánica Darwinion (http://www2.darwin.edu. ar/Proyectos/FloraArgentina/FA.asp; last accessed May, 2011).

\section{Environment of the Magellanic region}

The climate and vegetation patterns of the region follow a west to east gradient, mainly determined by the occurrence of strong and almost constant westerly winds (McQueen, 1976; Moore, 1983; Pisano, 1977; Figure 1b, c). In the western sector, the Magellanic moorland (Pisano, 1983) developed under a marked oceanic climate, with extreme rain and also cold. Rain falls evenly throughout the year and temperatures are uniformly low, with little variation during the day and low annual oscillations. However, summer temperatures are high enough to prevent the occurrence of permafrost. The vegetation is typically treeless, dominated by communities of small and dwarf shrubs, herbs and bryophytes. Cushion bogs of Astelia pumila and Donatia fascicularis are a major component of the region. It has been suggested that the impermeable substrate, consisting of compact diorite, is the limiting factor for the presence of forest in the outer archipelagos (Godley, 1960). Mean summer temperatures are well below the limit normally required for forest growth $\left(10.5^{\circ} \mathrm{C}\right.$; McQueen, 1976). Nevertheless, dwarf rain forest patches have been reported on the most exposed western coast, on Isla Desolación (Young, 1972). Towards the east, forest patches of the evergreen Nothofagus betuloides and deciduous Nothofagus antarctica appear frequently in favourable sites with adequate drainage and shelter from wind.

The evergreen forest of Nothofagus betuloides (Promis et al., 2008; Veblen et al., 1996) becomes continuous with a decrease in precipitation and a consequent increase in summer temperatures. Nothofagus betuloides is moisture demanding. Its distribution is associated with an oceanic cold temperate climate. It forms continuous forest in a precipitation range from about $600 \mathrm{~mm}$ up to about $1750 \mathrm{~mm}$ to the west of Peninsula Brunswick. Below the canopy, a dense layer of bryophytes and Hymenophyllum cover the ground and fallen logs. Nothofagus betuloides forms forests from sea level to upper treeline. With increasing altitude, small trees or prostrate shrubs of Nothofagus antarctica occur above the Nothofagus betuloides treeline. In other occasions, the forest 
gives way at the treeline directly to subalpine cushion vegetation and occasionally prostrate Nothofagus antarctica. Pure forests of Nothofagus betuloides occur mainly in inland locations, and at the treeline in places protected from strong winds. Near the coast below $200 \mathrm{~m}$ a.s.l., Drimys winteri becomes frequent, forming mixed forests with Nothofagus betuloides. Below c. $100 \mathrm{~m}$ a.s.l. of elevation Raukaua laetevirens joins the canopy forming the characteristic coastal mixed forest. In peaty soils Pilgerodendron uviferum becomes dominant within these coastal forest communities.

Further to the east, in less oceanic climate, the mixed evergreen-deciduous Nothofagus betuloides-Nothofagus pumilio forest develops, where Nothofagus betuloides dominates the more humid and poorly drained sites. With decreasing rainfall, forest composition changes gradually to dominance of Nothofagus pumilio at about $600 \mathrm{~mm}$ annual precipitation. These forests are replaced by Nothofagus antarctica low forest and shrublands where precipitation drops to $400 \mathrm{~mm}$. Shrubby tussock grassland of Festuca occurs below $300 \mathrm{~mm}$ precipitation.

Ice fields and a number of smaller glaciers occur today in the highest parts of the Andes and the archipelago (Lliboutry, 1998), with particular centres in the Cordillera Darwin, Isla Hoste, Isla Santa Inés and Gran Campo Nevado (Figure 1a). The closest volcanic centre is Mount Burney, located $160 \mathrm{~km}$ to the northwest, at $52^{\circ} 20^{\prime} \mathrm{S} 73^{\circ} 24^{\prime} \mathrm{W}$. Mt Burney is the southernmost active stratovolcano in the Andes, which has produced two large explosive and few other minor eruptions during the Holocene (Kilian et al., 2003; Stern, 2008).

The region has been continually occupied by people since at least 14,000 cal. yr BP and throughout the Holocene (Borrero, 2008) using marine and inland resources. There is no evidence of any cultivation or forest clearance activity before the arrival of Europeans 500 years ago. Therefore, it can be assumed that human effects on vegetation were negligible or non-existent over most of the period since the last glacial maximum, particularly in the westernmost region of Tierra del Fuego.

\section{Site description}

The studied site, Ballena $\left(53^{\circ} 38.97 \mathrm{~S} ; 72^{\circ} 25.24 \mathrm{~W}\right)$, is a $6 \mathrm{~m}$ deep lake, 1 ha surface, located on the northern slopes of Isla Santa Inés, in the southeast of Peninsula Ulloa, Magallanes region of Chile (Figure 1a, d). The lake is situated on a plateau, $70 \mathrm{~m}$ a.s.l. Its hydrological catchment area is negligible and it can therefore be assumed that inwash of material into the lake must have been low throughout most of its history. The surrounding vegetation consists of a mosaic of moorland plants dominated by Cyperaceae and Juncaceae species intermingling with the cushion plants Astelia pumila and Donatia fascicularis. Few Nothofagus betuloides krummholtz and small specimens of Drimys winteri occur in the vicinity of the lake. Woodland patches dominated by Nothofagus betuloides are frequent on the coastal areas within a few kilometres of the lake. Pilgerodendron uviferum is occasionally found within the area, associated with Nothofagus betuloides. Glaciers from the Santa Inés ice cap (the largest in the archipelago) occur about $15 \mathrm{~km}$ to the southwest of the lake.

\section{Methods}

\section{Sampling procedure and sediment analyses}

Sediment cores from Lake Ballena (Figure 1d) were collected from a boat in the deepest part of the lake, in February 2001. Three parallel cores, about $1 \mathrm{~m}$ apart, were recovered using a Livingstone-type piston sampler (Wright, 1967). Core segments were extruded in the field, wrapped in plastic film and aluminium foil and stored in plastic half pipes. The uppermost part of the sequence, containing the sediment-water interface, was recovered with a Hongve gravity sampler (Wright, 1990). This core was sectioned at contiguous $2 \mathrm{~cm}$ intervals on site, and stored in plastic bags. All samples were stored in a cold room at $4{ }^{\circ} \mathrm{C}$ prior to analyses. The longest core was described in detail in the laboratory and analysed for magnetic susceptibility, loss on ignition (LOI) and pollen. Magnetic susceptibility was measured using a Bartington Instruments meter with a MS2E1 surface scanning sensor (Bartington Ltd, UK). The sensor was connected to an automatic core logging system, TAMISCAN-TS1 (http://www. geol.lu.se/palmag/; last accessed July 2011). Measurements were made at $3 \mathrm{~mm}$ intervals, to obtain a continuous record. Magnetic susceptibility measurements were used to assist in locating basaltic tephras. Organic matter content of the sediment was estimated by LOI. Samples were oven-dried for $24 \mathrm{~h}$ at $105^{\circ} \mathrm{C}$ and then heated in a muffle furnace for $5 \mathrm{~h}$ at $500^{\circ} \mathrm{C}$. Results are expressed as percentages of weight loss of the sediment related to the dry weight of the samples before combustion (Heiri et al., 2001).

\section{Pollen analyses}

Volumetric subsamples of $0.5 \mathrm{~cm}^{3}$ were taken with a syringe of $0.5 \mathrm{~cm}$ diameter at predetermined intervals for pollen analysis. Samples were prepared in accordance with standard methods described by Bennett and Willis (2001), excluding sieving. Lycopodium clavatum tablets (Stockmarr 1971, 1972) were added to enable estimation of pollen concentration and accumulation rates. A minimum of 500 pollen grains and spores of terrestrial vascular plants were counted. Pollen and spores of obligate aquatic plants, Bryophyta and Fungi were excluded from the total pollen sum. Pollen grains and spores were identified with reference to Boros and Járai-Komlódi (1975), Heusser (1971), Markgraf and D'Antoni (1978), Morbelli (1980) and the reference collection held at the Department of Palynology and Climate Dynamics, University of Göttingen. Pollen taxonomy follows the information on present plant distribution from the Flora of Tierra del Fuego (Moore, 1983) and the online data base of Flora Chilena (http://www.florachilena.cl/nuevo/index.php; last accessed May 2011), linking morphological pollen types to species and genera occurring in southern Patagonia. Gunnera magellanica/lobata pollen is assumed to be mostly Gunnera magellanica as this is the common and widespread species present today. Although Gunnera lobata can be locally present, it mainly reproduces vegetatively (Molina, 1978). In addition, Gunnera magellanica seeds are found in the record, proving the presence of this species in the surroundings of the lake.

In order to gain information on the different species of Nothofagus within the Nothofagus dombeyi pollen type, the number of pores of Nothofagus pollen was counted to calculate pore frequency in 34 samples, following von Post (1929).

\section{Numerical analyses}

Zones were defined numerically in the pollen percentage diagram, using optimal splitting by information content (Bennett, 2009). The number of statistically significant zones was evaluated using the broken stick model (Bennett, 1996). Principal component analysis (PCA) was applied to display the relationships between the samples, with the direction of variation of the species indicative. The analysis was carried out on the covariance matrix of the taxon-combined percentage data. Palynological richness was determined by rarefaction analysis (Birks and Line, 1992), with a standard pollen sum of $500\left(\mathrm{E}_{(\mathrm{T} 500)}\right)$. The small size of Ballena indicates that it collects a large proportion of pollen from its near surroundings, while it also accumulates pollen coming from the region, thus pollen taxonomic richness is probably closer to Whittaker's gamma diversity or within landscape diversity 
Table I. Radiocarbon dates from Ballena. Material analysed: bulk organic matter.

\begin{tabular}{lccc}
\hline Sample depth $(\mathrm{cm})$ & $\begin{array}{l}\text { Uncalibrated age } \\
\left({ }^{14} \mathrm{C} \text { yr BP }\right)\end{array}$ & $\begin{array}{l}\text { Calibrated age weighted average/ } \\
\text { cal. yr BP }(2 \sigma \text { interval })\end{array}$ & Laboratory no. \\
\hline $\begin{array}{l}\text { Gravity core } \\
604-606\end{array}$ & $2450 \pm 20$ & $2430(2320-2710)$ & UBA-15494 \\
Piston core & & $1260(1110-1340)$ & UBA-12792 \\
$601-601.5$ & $1380 \pm 20$ & $1630(1440-1820)$ & UBA-9745 \\
$610-610.4$ & $1770 \pm 25$ & $2220(2000-2340)$ & UBA-9746 \\
$625-625.5$ & $2240 \pm 20$ & $5440(5320-5580)$ & UBA-9747 \\
$638.5-639$ & $4870 \pm 25$ & $9090(8790-9390)$ & UBA-9748 \\
$642.6-642.9$ & $4490 \pm 25$ & $13,650(13,380-13,930)$ & UBA-9749 \\
$651.6-652$ & $8210 \pm 30$ & $16,440(15,140-16,940)$ & UBA-9750 \\
$665-665.4$ & $11,800 \pm 35$ & & UBA-975I \\
$678.6-678.9$ & $13,360 \pm 40$ & &
\end{tabular}

${ }^{\text {a } O u t l i e r ~ d a t e, ~ n o t ~ u s e d ~ i n ~ t h e ~ a g e-d e p t h ~ m o d e l . ~}$

(Odgaard, 2007; Whittaker, 1977). The amount of palynological change or compositional turnover for the entire sequence was estimated using detrended canonical correspondence analysis (DCCA) (ter Braak, 1986), constrained by sample age. The length of the first time-constrained DCCA axis provides an estimate of the amount of compositional turnover in the time period considered (Birks, 2007). Rate of vegetational change was quantified using chord distance as the dissimilarity measure between adjacent samples, interpolated to equal time intervals of 250 calibrated years. No smoothing of the data was applied. This approach can give spuriously high values if the adjacent pair of samples are so close that pollen counting uncertainty exceeds the underlying change in proportions. For the Ballena data, the closest sampled section shows no significant change in calculated rate of change values, giving confidence that these values reflect underlying patterns and are not artefacts of the sampling interval. Zonation, PCA and rate of change analyses were carried out on taxa exceeding $1 \%$ of the total terrestrial sum. DCCA analysis was implemented on all taxa within the terrestrial pollen sum, with detrending by segments and non-linear rescaling. As a result, sample scores are scaled in standard deviation (SD) units of compositional turnover with time (=beta diversity: diversity between habitats or communities within a landscape) (Hill and Gauch, 1980). Rare taxa were not downweighted. Square root transformation of the data was applied during zonation, PCA and DCCA.

\section{Chronology}

The chronology of the sediment record is based on nine AMS radiocarbon dates on bulk organic matter (Table 1), obtained at CHRONO Centre, Queen's University Belfast, UK (UBA). Results were calibrated against the Southern Hemisphere calibration curve, SHCal04 (McCormac et al., 2004) and the IntCal09 calibration curve (Reimer et al., 2009) for the two oldest dates, using the BCal online system (Buck et al., 1999; http://bcal. sheffield.ac.uk; last accessed July 2010). Numerical descriptions of the confidence intervals were obtained. Age-depth models for both cores were constructed by linear interpolation using psimpoll 4.27 (Bennett, 2009). Derived sample ages were used for connecting the gravity core to the piston core. Sediment surface was assumed to have an age of $-50 \pm 50 \mathrm{BP}$. Confidence intervals for the age-depth plots were obtained by simulation, drawing random ages from the probability distributions of the calibrated ages (Bennett, 1994). The tephra layer at 639-642.5 cm depth was subtracted to construct the age-depth model. The two dates enclosing the tephra layer showed an age reversal of $c .400$ years (Table 1). Tephra deposition may have caused lake sediment disturbance, as well as it may have induced changes on the vegetation cover around the lake. The presence of corroded pollen in samples above the tephra layer suggests the input of reworked (older)

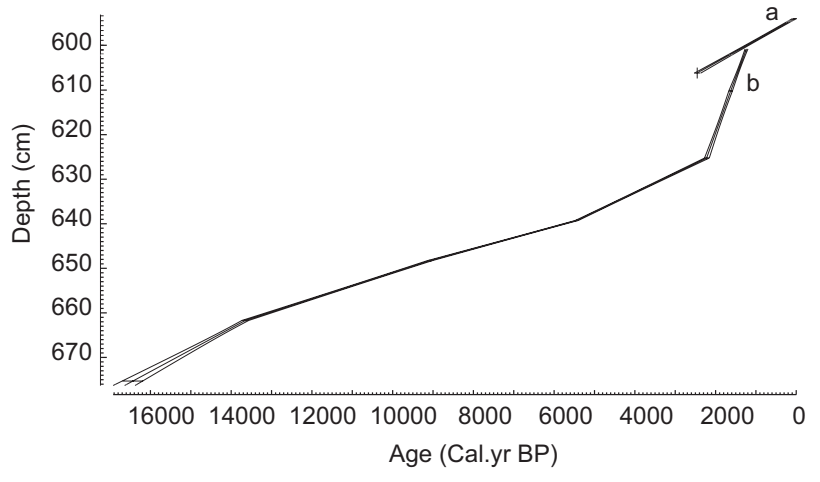

Figure 2. Age-depth models for the Ballena sediment cores. a: Gravity core; b: piston core.

material into the lake. Thus, the date obtained above the tephra layer was considered as outlier and not used for the age-depth model. Ages are given as calendar years before present (cal. yr BP) where 'present' is defined as AD 1950. Dates obtained from the age-depth models are rounded to the nearest 100 years without indicating errors.

Diagrams, rarefaction, rate of change, accumulation rates, zonation, PCA and age-depth models were carried out using psimpoll (Bennett, 2009). DCCA was implemented using CANOCO 4.5 (ter Braak and Šmilauer, 2002).

\section{Results}

\section{Chronology and sediment accumulation}

A complete and continuous sediment sequence of $86 \mathrm{~cm}$ length was obtained from the centre of the lake, encountering solid bedrock at a depth of $680 \mathrm{~cm}$ below water surface. The age-depth model (Figure 2) indicates a basal age of 16,700 cal. yr BP for the sequence, which compares well with estimates for the deglaciation of the area between 17,500 and 17,150 cal. yr BP (Coronato et al., 2004; Kilian et al., 2007; McCulloch et al., 2000). Sedimentation rate is slow throughout the sequence, which is probably a consequence of the small catchment area, resulting in minimal input of inorganic material into the lake. Similar sedimentation rates are found in two comparable lakes nearby, suggesting that the low sediment accumulation of Ballena is a regional feature. The age-depth model indicates a major change in the rate of sediment accumulation around 2500 cal. yr BP, which is followed by decrease in LOI and increase in magnetic susceptibility values. Changes in catchment vegetation may have increased the input of inorganic material into the lake during this period. Changes in sediment composition are displayed in Figure 


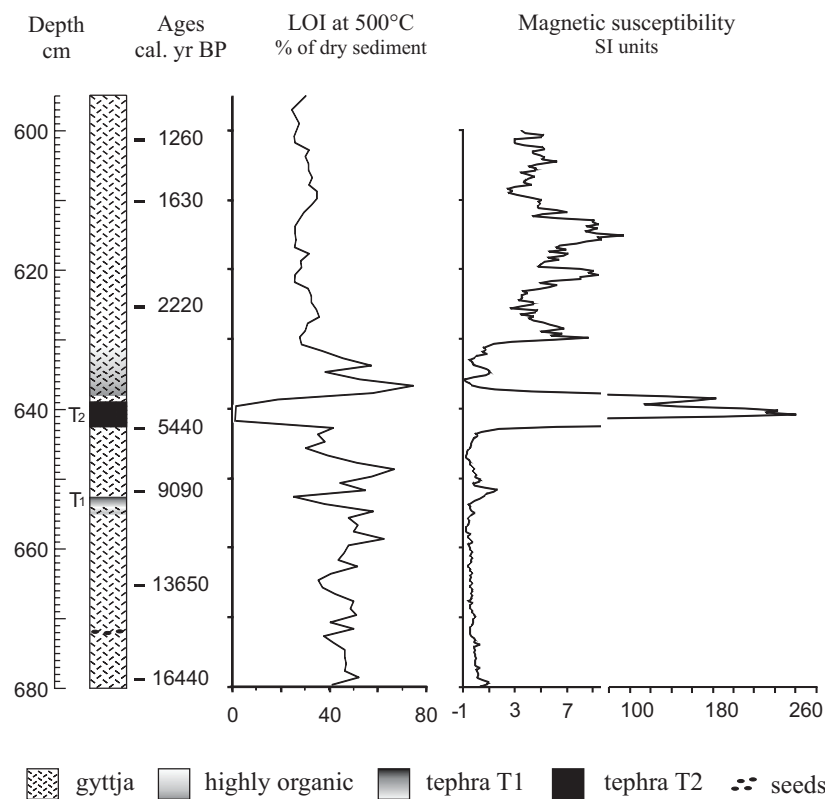

Figure 3. Sediment description, loss on ignition, magnetic susceptibility and chronology from Ballena, plotted against depth (cm below water level). T2: Mt Burney 2 eruption. Seeds: Gunnera magellanica.

3 and described in Table 2. Two tephra layers are recognized: a thin light-grey tephra layer at $652-652.5 \mathrm{~cm}$ depth and a consolidated light brown tephra layer recorded between 639 and 642.5 $\mathrm{cm}$ depth. Both tephras are characterized by peaks in magnetic susceptibility. Comparison of the geochemical composition of glass shards with reference data (Stern, 2008) indicates that the younger tephra was produced by the large eruption of Mt Burney, MB2 (Sarah Coulter, personal communication, 2010).

\section{Vegetation history}

The pollen record from Ballena has been divided into five pollen assemblage zones (Table 3, Figure 4). The record illustrates the vegetation development since shortly after deglaciation, which is described in Table 3. The pollen concentration and accumulation rates (PAR) at Ballena (Figure 4b, Table 4) give insight into the direction of vegetation change around the lake, complementing pollen percentages (Figure 4a). However, the sedimentation history of the core is complex with periods of slow sedimentation rate and sediment focusing (cf. Bennett, 1983; Giesecke and Fontana, 2008). In these cases, PAR is reflecting sedimentation history rather than changes in plant abundance. For example, the pronounced increase in the Nothofagus curve and other taxa at 9400 cal. yr BP is probably caused by extremely slow sediment accumulation. Ignoring these peaks, noticeable is the gradual decline of Lycopodium magellanicum accumulation rates, unlike its percentages, which suddenly declined with the rise of Nothofagus. This is a common artefact of percentage values when a high pollen producer arrives in a low pollenproducing vegetation. The effect of tephra deposition and the re-bounce of the vegetation are more evident in the accumulation rate data, but also here short-term changes in sediment accumulation could have enhanced the pattern. Within pollen zone B-5, the population of Nothofagus was most likely as large or smaller than before the deposition of volcanic ash (zone B-3) with values of about 400 grains $/ \mathrm{cm}^{2}$ per yr. During the last 2200 years, pollen accumulation rates increased (not shown in Figure $4 b$ ), probably because of sediment focusing, and therefore do not indicate changes in the abundance of species. However, pollen concentrations and percentage suggest a gradual decline of the Nothofagus woodland towards the present.

The pore frequency of Nothofagus pollen grains shows different distributions (Figure 5). The older samples contain higher proportions of pollen grains with 6 pores, while grains with 4 pores are more frequent in younger samples. These values correspond well to the average numbers of apertures of about $4(2 \%), 5$ (71\%), 6 (25\%) for Nothofagus antarctica and 4 (14\%), 5 (74\%), $6(10 \%)$ for Nothofagus betuloides obtained by von Post (1929). Thus, the samples dating between 11,000 and 9000 cal. yr BP probably contain high proportions of Nothofagus antarctica pollen, while samples afterwards have probably more Nothofagus betuloides pollen.

\section{Diversity, turnover and rates of change}

Overall palynological richness rises from the beginning of the sequence towards the present, in association with continuous appearance of new taxa through the record (Figure 4a). The highest values are estimated for the late Holocene, between 2000 and 1000 cal. yr BP. Pollen richness is low between 11,000 and 9000 cal. yr BP, coincident with the development of Nothofagus woodland within the region, a period of changing landscape. However, the lowest richness values are recorded in zone B-4, after the deposition of volcanic ash c. 5200 cal. yr BP. Pollen richness stays generally constant within zone B-2 and B-3, particularly between 13,000 and 11,500 cal. yr BP and 8500 and 5150 cal. yr BP, periods of apparent landscape stability.

Total turnover estimates for the entire pollen record is high: $2.03 \mathrm{SD}$ (Figure 4a). This gradient length indicates that samples at either end of the sequence differ markedly in their pollen

Table 2. Sediment description.

\begin{tabular}{|c|c|c|}
\hline $\operatorname{Depth}^{\mathrm{a}}(\mathrm{cm})$ & Age cal. BP & Sediment characteristics \\
\hline $594-631$ & Present-3500 & $\begin{array}{l}\text { dark brown gyttja, LOI between } 26 \text { and } 36 \% \text { and higher magnetic susceptibility values, abundant remains } \\
\text { of aquatic mosses, particularly at } 618 \mathrm{~cm}\end{array}$ \\
\hline $631-638$ & $3500-5100$ & $\begin{array}{l}\text { black to dark brown gyttja, highly organic, with a drop in LOI values and a slight rise in magnetic } \\
\text { susceptibility at } 635 \mathrm{~cm} \text {, LOI peak to } 75 \% \text { at } 637 \mathrm{~cm}\end{array}$ \\
\hline $638-639$ & $5100-5400$ & dark brown gyttja, LOI drop towards the underlying tephra layer \\
\hline $639-642.5$ & 5400 & light brown tephra (Mt Burney 2 eruption), silt grain size, decrease in LOI, peak in magnetic susceptibility \\
\hline $642.5-652.5$ & $5400-9300$ & dark brown gyttja, abundant remains of aquatic mosses at $652 \mathrm{~cm}$ \\
\hline $652.5-654$ & $9300-9800$ & $\begin{array}{l}\text { tephra shards, at the lower boundary mixed with underling sediments over I cm, LOI drops to } 25-38 \% \\
\text { and magnetic susceptibility increases slightly }\end{array}$ \\
\hline $654-655$ & $9800-10,200$ & black gyttja, abundant remains of aquatic mosses at $655 \mathrm{~cm}$ \\
\hline $655-680$ & $10,200-16,700$ & $\begin{array}{l}\text { dark brown gyttja, , LOI between } 36 \text { and } 63 \% \text {, low magnetic susceptibility values, abundant Gunnera } \\
\text { magellanica seeds at } 672 \mathrm{~cm}\end{array}$ \\
\hline
\end{tabular}


Table 3. Vegetation history.

\begin{tabular}{|c|c|c|c|}
\hline Zone & Age cal. yr BP & Pollen zone characteristics & Interpretation \\
\hline B-5 & Present -4500 & $\begin{array}{l}\text { Slow decline of Nothofagus to its present abundance; re- } \\
\text { establishment of pollen diversity and PAR values; increased } \\
\text { abundance of Drimys winteri; frequent occurrence of } \\
\text { Lepidothamnus fonkii; increased proportion of sedges, Caltha } \\
\text { and Astelia pumila; start of the Isoëtes savatieri curve with } \\
\text { maximum percentages }(20 \%) \text { at } 2000 \text { cal.yr BP }\end{array}$ & $\begin{array}{l}\text { Recovery of plant taxa affected by the deposition of } \\
\text { tephra; reduction of bog communities and increase of } \\
\text { mixed Nothofagus - Pilgerodendron uviferum - Drimys } \\
\text { winteri woodland; establishment of Isoëtes savatieri in } \\
\text { the lake }\end{array}$ \\
\hline
\end{tabular}

B-4 4500-5200 Decline of Cyperaceae, Donatia fascicularis, Caltha and Astelia pumila pollen; increase of Nothofagus, Misodendrum, Pilgerodendron uviferum; drop of pollen accumulation rates and pollen richness values

B-3 5200-9900 Dominance of Nothofagus pollen, with maximum abundance at around 9500 cal. yr BP; onset of the Misodendrum, Pilgerodendron uviferum and Myrteola nummularia curves; increased proportions of Donatia fascicularis and Astelia pumila; decline of postglacial taxa; components of the evergreen forest appeared: Drimys winteri, Blechnum magellanicum, Sticherus quadripartitus

B-2 9900-13,600 Rise of the Nothofagus curve at 10,500 cal. yr BP; maximum abundance of Empetrum rubrum and Poaceae; increase abundance of moisture demanding taxa: Caltha, Drapetes muscosus; start of the continuous curve of Astelia pumila at I I,800 cal. yr BP; decline of Sporormiella fungal spores

B-I $\quad 13,600-16,700$ and Gunnera magellanica pollen; frequent occurrence of heath, grass, sedge and fern species together with Azorellatype, Nanodea muscosa and Dysopsis glechomoides; start of the continuous curve of Caltha at I5,000 cal. yr BP; onset of the Nothofagus pollen curve at $14,400 \mathrm{cal}$. yr BP; maximum proportion of Sporormiella fungal spores

Abrupt decline of cushion plants and herbaceous vegetation, as well as decline of vegetation cover and loss of plant diversity as a consequence of volcanic fallout

Abrupt shift in vegetation composition to Nothofagus woodland/moorland mosaic; maximum extension of Nothofagus woodland; establishment of Pilgerodendron uviferum and Myrteola nummularia together with the immigration of rain forest elements

Establishment and expansion of Nothofagus within a mosaic of ericaceous heath and grassland; increase humidity and expansion of cushion plants; decreasing numbers of herbivores visiting the site

Pioneer vegetation growing on the recent deglaciated terrain; mosaic of cold-wet herbaceous plants: ferns, Gunnera magellanica, grasses, sedges and heath; treeless landscape; presence of large-herbivores around the site

Table 4. Lateglacial-Holocene Nothofagus pollen accumulation rates (grains $/ \mathrm{cm}^{2}$ per $\mathrm{yr}$ ).

\begin{tabular}{lllllll}
\hline Site & Present vegetation & Lateglacial & & Holocene & \\
\hline Ballena & Moorland & B-1 & B-2 & B-3 & B-4 & B-5 \\
& & I & 35 & & 550 & 400 \\
Puerto Harberton & Deciduous forest & 350 & & & 8000 & 8500 \\
Ushuaia 2 & & 150 & 300 & & & \\
Ushuaia 3 & & 300 & & & \\
\hline
\end{tabular}

Ballena: average values for each zone (this study); Puerto Harberton and Ushuaia: maximum values for the Lateglacial and late Holocene (Heusser, 1998). Notice values in bold for comparison.

composition, c. $50 \%$ of the total assemblages (Hill and Gauch, 1980). A high amount of compositional and rate of change occur at the zone B-2/B-3 transition, when heath and grassland communities are replaced by Nothofagus woodland. Thereafter, turnover decreases gradually and becomes low towards the present, with the development of bog habitats and shift in Nothofagus species to dominance of Nothofagus betuloides. With Nothofagus as the main contributor to the pollen sum, there is less potential for compositional change. Within the decreasing trend, there is however a rapid and drastic turnover after the Mt Burney 2 volcanic eruption. The curve of rate of change also shows a sharp increase indicative of rapid changes at the time of tephra deposition.

\section{Principal components analyses}

The results of PCA (Figure 6) separate the samples into clusters that correspond well with the numerical zonation of the record. The first axis, explaining $82 \%$ of the variance, splits the samples according to their proportion of Lycopodium magellanicum and Gunnera magellanica versus Nothofagus dombeyi-type pollen. On the second axis, samples are separated according to their proportion of Astelia pumila and Caltha versus Misodendrum and Pilgerodendron uviferum pollen. Samples predating the arrival of
Nothofagus cluster together in a narrow band (zones B-1, B-2). The sequence begins with samples dominated by Lycopodium magellanicum and Gunnera magellanica on one side of the band (zone B-1) to continue with samples containing higher proportions of heath pollen taxa at the other end (zone B-2). Samples containing Nothofagus pollen (zones B-3, B-5), are arranged along a line, representing the variable amount of bog pollen taxa. Thus, samples from zone B-3 contain higher proportions of Astelia pumila, Caltha, Donatia fascicularis and Myrteola nummularia than samples from B-5. Samples from zone B-4 form a distinct group which corresponds to the decline of these taxa and an increase in Misodendrum and Pilgerodendron uviferum. The PCA, which has no stratigraphic constrains, reveals the similarity of zones B-3 and B-5.

\section{Discussion}

\section{Deglaciation and Lateglacial vegetation}

Multiple glacier advances are identified in the Straits of Magellan area during the last glaciation (Coronato et al., 2004; McCulloch et al., 2005). The Magellan glaciers reached their maximum some time between 23 and $25 \mathrm{ka}$, and the last extensive ice advance occurred at around $17.5 \mathrm{ka}$. Afterwards, a sudden rise in 


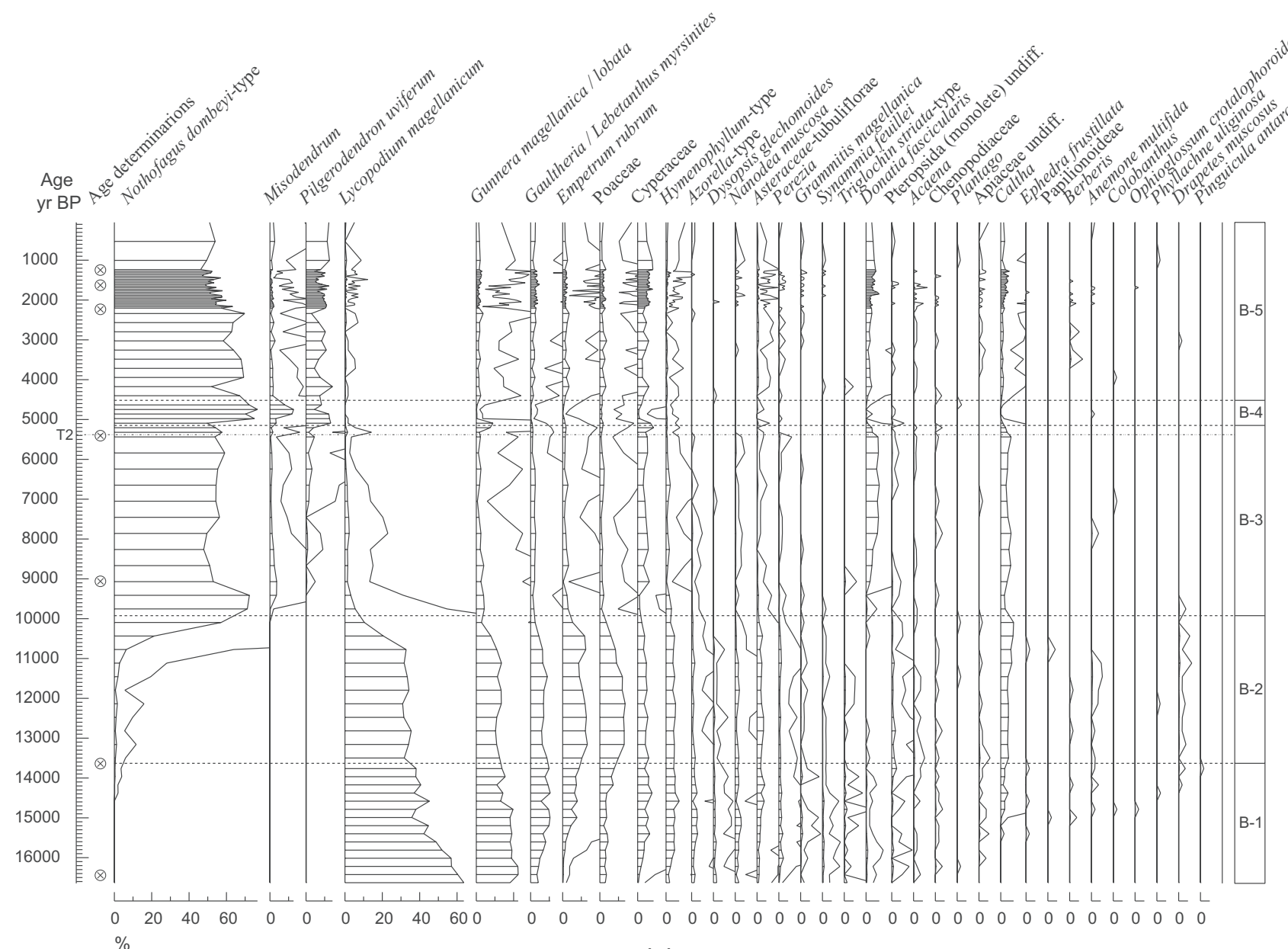

(a)
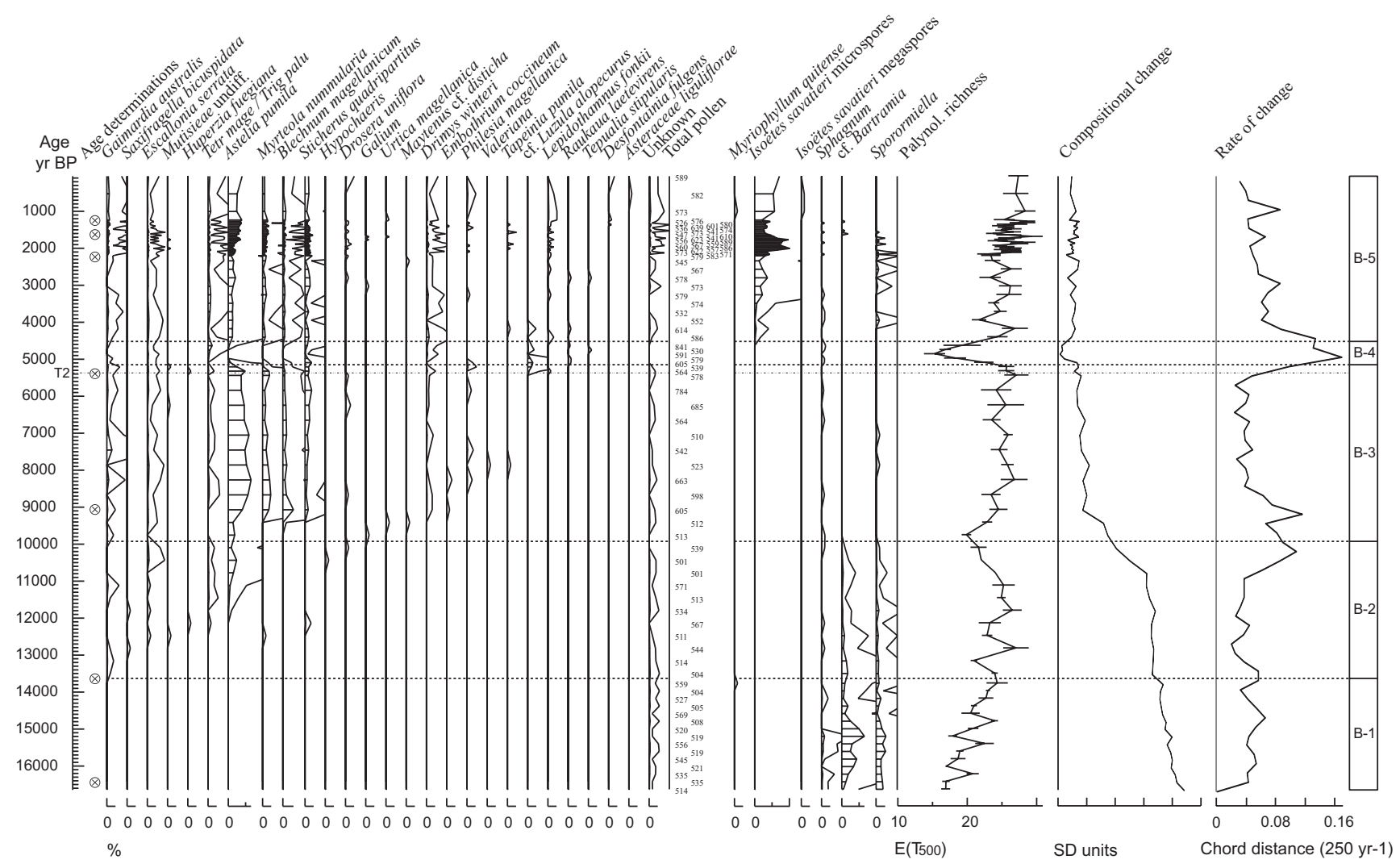


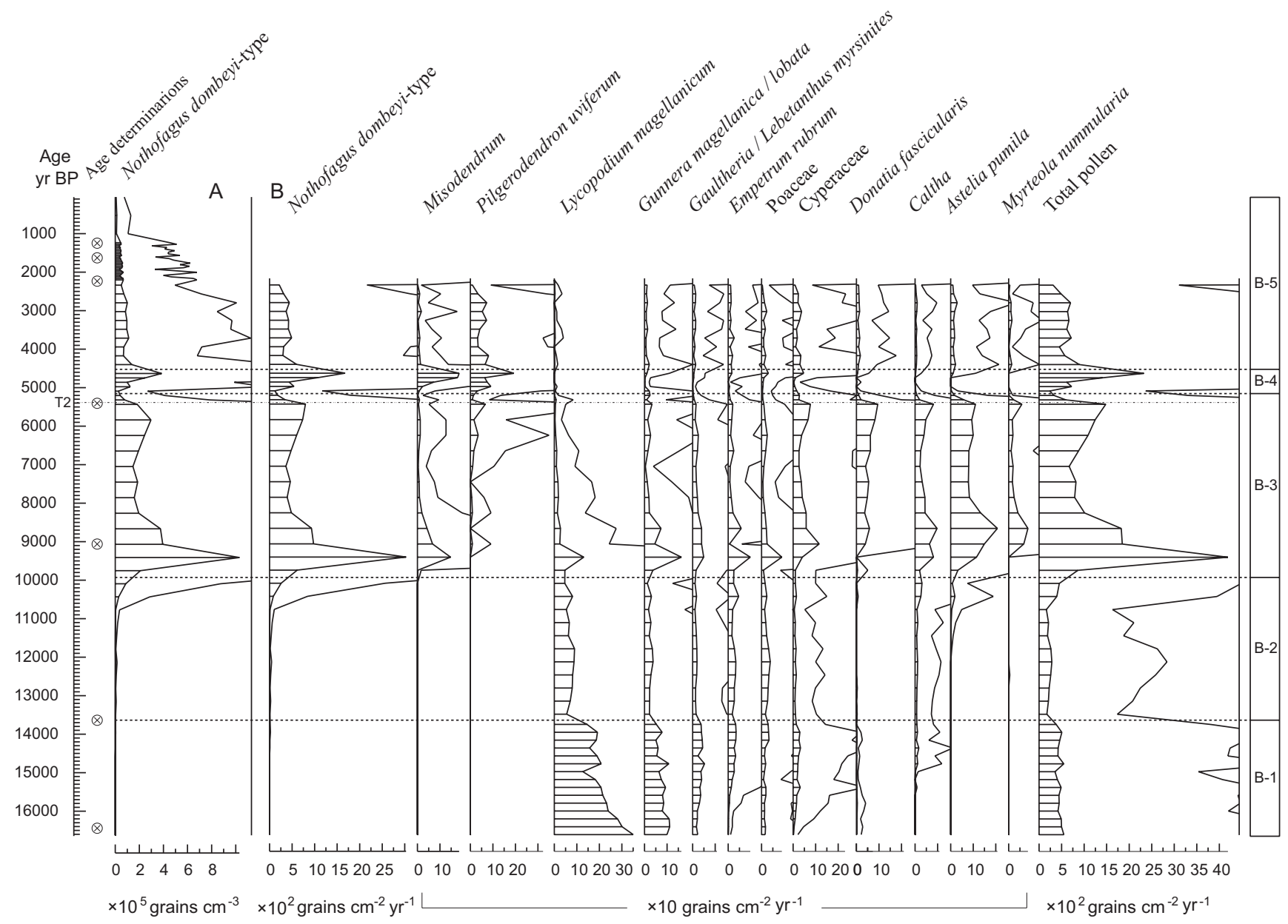

(b)

Figure 4. (a) Percentage pollen diagram from Ballena, including palynological richness (base sum of 500), compositional change or turnover (in standard deviation units) and rate of change per 250 cal. years. Tetr mage/Trig palu: Tetroncium magellanicum/Triglochin palustris. (b) A: Nothofagus pollen concentration curve. B: Pollen accumulation rate diagram of selected taxa from Ballena. Outline curve represents an exaggeration of $10 \times$ for minor taxa.T2 indicates the position of the tephra layer from the Mt Burney 2 eruption. Notice different scales.

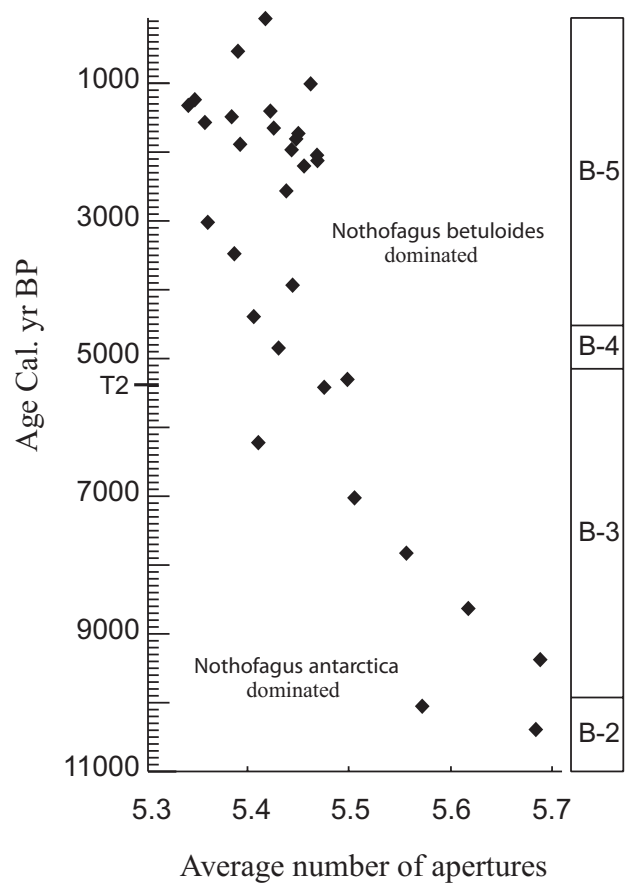

Figure 5. Distribution of the average number of apertures of Nothofagus pollen at Ballena. Oldest sample: $n=107$; all other samples $n=$ between 214 and 429.T2: Mt Burney 2 eruption. The pollen zones boundaries are indicated.

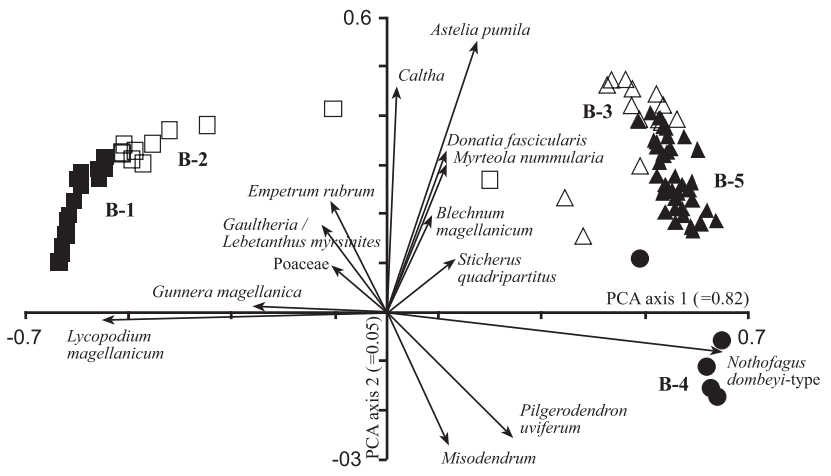

Figure 6. PCA distance biplot of the taxa combined pollen percentage data from Ballena.

temperature of $4-6^{\circ} \mathrm{C}$ (Heusser et al., 1981; Hulton et al., 2002) initiated deglaciation, synchronously over $16^{\circ}$ of latitude along the Patagonian Ice Sheet (McCulloch et al., 2000). Deglaciation was extremely rapid. Modelling studies suggests a reduction to nearly half of the LGM ice sheet volume after 300 years and $80 \%$ after 2000 years (Hulton et al., 2002). Following the initial warming, there was a lagged response in precipitation reflected on the return of the westerlies to their present latitude by 14,300 cal. yr BP (McCulloch et al., 2000). 
The northern coast of Isla Santa Inés, where Ballena is situated, was already ice free soon after the onset of deglaciation and lake sedimentation started as early as 16,700 cal. yr BP. As a consequence of the increase in temperature and the retreat of ice streams, vast areas of uncovered ground were rapidly colonized by pioneer vegetation. A rich field layer, covering the immediate surroundings of the lake, was already established at the time that sedimentation in Ballena began. It consisted of pioneer taxa such as lycopods (Lycopodium magellanicum), diverse ferns (Hymenophyllum spp., Grammitis magellanica, Synammia feuillei), cushion plants (Donatia fascicularis, Azorella), nitrogen-fixers (Gunnera magellanica), shrubs (Gaultheria, Empetrum rubrum) and mosses (cf. Bartramia). This earliest vegetation has features in common with recent periglacial plant communities of primary succession that developed after glacial retreat (Pisano, 1971).

With soil development and increased humidity, the initial landscape was invaded consecutively by more moisturedemanding taxa such as Caltha and the cushion plants Drapetes muscosus, Gaimardia australis and Astelia pumila (pollen zones B-1, B-2). Changes in species abundance, particularly the increase of grasses and heaths occurred during zone B-2. The widespread occurrence of Empetrum rubrum may have favoured the regional establishment of Nothofagus. Facilitation of Nothofagus antarctica seedlings by the prostrate shrub Empetrum rubrum has been described by Henríquez and Lusk (2005) on recently deglaciated areas.

During the Lateglacial period glacier advances are documented within the region and correlated to an increase in precipitation on the western side of the Andes (McCulloch and Davies, 2001; McCulloch et al., 2000) or to colder episodes expanding the Antarctic Cold Reversal and/or the Younger Dryas Chronozone (McCulloch et al., 2005; Rabassa et al., 2000). These glacier fluctuations have occurred to a different extent, probably in relation to differences in their drainage systems (Kilian et al., 2007). There are also a number of palaeoecological studies that suggests cooling during the Lateglacial and Holocene transition on Tierra del Fuego (Heusser, 1993; Heusser and Rabassa, 1987; Heusser et al., 2000)

The stratigraphy of the Ballena core does not show any indication of glacial advances within the catchment of the lake after the LGM. Moreover, there is no indication in the sediment stratigraphy (Figure 3) nor in the pollen composition (both percentage and accumulation rates, Figure $4 \mathrm{a}$ and $\mathrm{b}$ ), of a major cold reversal during the Lateglacial. The pollen diagram rather indicates continuing climate warming with sequential changes in species abundance, without reverting to previous states, as new taxa arrive, initiating new competitive interactions between the new and the resident species. Despite these changes in vegetation composition, the vegetation cover did not change significantly during the Lateglacial (Figure 4b). This evidence is consistent with other pollen records from Fuego-Patagonia (Fesq-Martin et al., 2004; McCulloch and Davies, 2001; Markgraf, 1993b) and from the Chonos Archipelago and Taitao peninsula region (Bennett et al., 2000; Haberle and Bennett, 2004).

The Ballena record shows the occurrence of the dung fungus Sporormiella, in particular during the Lateglacial period, suggesting the presence of large-herbivore populations in the environment. At the maximum glacial extent, see level was lower than today and the coastline was located far to the west (Rabassa et al., 2000). Sectors of dry land probably existed at the time, which would have presented opportunities for animals to move between the continental mainland and the islands. Among the Lateglacial fauna known for the region, the huemul (Hippocamelus bisulcus), a medium-size deer, is the most likely to have occurred around the site. Huemuls have survived until the present, but their distribution range has decreased considerably and only small fragmented populations remain, mainly along the Patagonian Andes (Díaz and Smith-Flueck, 2000). The southernmost distribution of the huemul reached as far south as Isla Santa Inés (Díaz and SmithFlueck, 2000). Although extinct today from this island, there is a population inhabiting Isla Riesco (Díaz et al., 2007), north of Ballena across the Strait of Magellan. Huemuls prefer open areas, avoiding forest and moorland and show a strong preference for Gunnera magellanica in their diet (van Winden, 2006). Therefore, the Lateglacial conditions developed around Ballena would have been suitable for huemuls. The decline of Sporormiella spores coincides with the onset of the Holocene, and a change in vegetation composition. This change in habitat type may have lead to decreasing numbers of huemuls visiting the site.

\section{The spread of Nothofagus into western Tierra del Fuego}

The most significant change in vegetation composition around Ballena is the spread and expansion of Nothofagus. It has been suggested that Nothofagus survived the LGM at the eastern edge of the Magellan glacier (Markgraf and McGlone, 2005; Markgraf et al., 1995) from where it spread and established in the region. The postglacial increase of Nothofagus across Fuego-Patagonia has occurred between 13,000 and 9500 cal. yr BP (Borromei, 1995; Borromei et al., 2007; Fesq-Martin et al., 2004; Heusser 1989, 1990, 1994, 1995, 1998; McCulloch and Davies, 2001; Markgraf and Huber, 2010), apparently with no particular pattern in space.

An important aspect in the spread of Nothofagus remains the problem of determining local and regional presence based on pollen proportions. Nothofagus produces abundant wind-dispersed pollen that can be transported over long distances (e.g. Heusser, 1989). Therefore, it is difficult to judge at which point isolated trees established in the immediate surrounding of the lake. The low pollen production of the local vegetation together with the general openness of the landscape permits high proportions of fartravelled pollen to be encountered. In western Tierra del Fuego, where trees presumably spread contrary to the prevailing westerly winds, the chance of getting long-distance dispersed pollen is reduced. Here, the beginning of the continuous curve is interpreted as an indication of regional presence, and the sharp increase as the time of arrival around the site.

The onset of the continuous curve at Ballena, which coincides with the first Nothofagus pollen recorded, dates to about 14,400 cal. yr BP. But the abrupt rise of the curve occurs only at about 10,500 cal. yr BP, marking the establishment of local populations in the vicinity of the lake. Subsequently, the Nothofagus pollen curve declined slightly, reaching maximum local abundance after the Mt Burney 2 volcanic eruption. Thereafter, Nothofagus slowly declined to its present abundance.

The Nothofagus curve generally represents more than one species in most pollen diagrams. South of $50^{\circ}$ latitude three species of Nothofagus are present: Nothofagus antarctica, Nothofagus betuloides and Nothofagus pumilio, all represented by the same pollen Nothofagus dombeyi-type. Separation of the pollen of Nothofagus species within the type level is not regularly carried out in pollen investigations, because their key morphological characters are found to overlap between species (Heusser, 1971). Even so, it may be possible to estimate the relative contribution of the different species of Nothofagus to the pollen curve.

Few studies in the past have addressed the different vegetation histories of Nothofagus species, using the differing morphological features of the pollen grains. Von Post (1929), for example, used the ranges in aperture numbers of Nothofagus pollen as a means of identification. Changes in the aperture frequency at different levels in Lago Fagnano, Tierra del Fuego, can be interpreted as changes in forest composition shifting from Nothofagus antarctica predominating to Nothofagus pumilio dominating and 
back again to domination by Nothofagus antarctica (Von Post, 1929; see also Erdtman, 1943). Auer et al. (1955) used instead the thickness of the rim around the aperture, coupled with spine distribution and size of the pollen grains, to distinguish the species of Nothofagus. The pollen record from Isla Clarence, $100 \mathrm{~km}$ southeast of Ballena, shows the arrival of Nothofagus antarctica first, followed by Nothofagus betuloides and later by Nothofagus pumilio (Auer 1958, 1974). Markgraf and D'Antoni (1978) differentiated Nothofagus pollen according to spine density. The pollen records at La Misión (Markgraf, 1980) and Lago Yehuin (Markgraf, 1983) show the presence of Nothofagus antarctica pollen from the beginning of the sequence and the occurrence of Nothofagus pumilio pollen several thousand years later.

The Nothofagus pollen curve from Ballena might represent only two of the three species of Nothofagus, which occur today in the region: Nothofagus antarctica and Nothofagus betuloides, both able to take the role of pioneer species (Pisano, 1978; Veblen et al., 1996). Nothofagus antarctica and Nothofagus betuloides occur today as far west as Isla Desolación (Young, 1972), where precipitation is as high as $4000 \mathrm{~mm} / \mathrm{yr}$. Contrary, Nothofagus pumilio is a more mesic species, occurring further to the east, in less oceanic climate. The pollen diagram from Ballena shows the presence of moisture demanding taxa such as Hymenophyllum, Caltha and Astelia pumila along with Nothofagus pollen, suggesting that the site was always too wet for the local occurrence of Nothofagus pumilio.

The range in aperture number of Nothofagus pollen in samples from Ballena during the rise of the Nothofagus curve, dated between 11,000 and 9000 cal. yr BP, suggests that Nothofagus antarctica dominated the woodland around the lake during that time. However, the distribution of aperture frequency afterwards seems to indicate that the Nothofagus woodland shifted to a dominance of Nothofagus betuloides. It is not unlikely that Nothofagus antarctica was the first to arrive and to cause the steep rise in the pollen curve during the early Holocene followed shortly after by Nothofagus betuloides. Both species probably spread from Peninsula Brunswick to the western islands.

Nothofagus antarctica occurs today in a wide range of habitat types, often becoming common at less favourable sites for other tree species (Veblen et al., 1996). It is likely that at the LGM Nothofagus antarctica had a wider distribution, occupying diverse habitats, with higher population density than any other species of Nothofagus. Therefore, as soon as climate was suitable for the trees to spread and colonize new habitats, Nothofagus antarctica was in a pole position giving it a quick start that could have resulted in its first arrival. Later, Nothofagus betuloides, a stronger competitor, replaced Nothofagus antarctica. Competitive replacement of these two species of Nothofagus has been described by Armesto et al. (1992) in recently deglaciated terrain.

At 9000 cal. yr BP and coincident with the shift in Nothofagus species to dominance of the evergreen Nothofagus betuloides, Nothofagus pollen dropped $30 \%$ with the increase of the cushion plants Donatia fascicularis and Astelia pumila and the shrub Myrteola nummularia. In addition components of the rain forest appeared: Drimys winteri, Blechnum magellanicum and Sticherus quadripartitus, among others.

Modern ecological observations show that Nothofagus species colonize recently deglaciated terrain, and become abundant, 50100 years after ice retreat (Pisano, 1978; Sweda, 1987). The arrival of Nothofagus at Ballena and its later expansion occurred $\sim 4000$ years after the onset of its pollen curve and $\sim 6000$ years after the onset of vegetation succession. Several factors may have played a significant role in limiting its postglacial abundance and distribution. Climate could have limited the spread of the trees, for example through influence on reproductive success (Giesecke et al., 2010). Spreading between islands and against the prevailing winds may have also slowed the process. Additionally, extensive fires during the early Holocene at the eastern side of the Andes (Huber et al., 2004; Whitlock et al., 2007), from where Nothofagus would have spread, may have caused the trees to survive through long periods mainly by vegetative reproduction, restricting its dispersal rate.

An important aspect of the distribution of forest relicts at the maximum extent of the glaciers are their abundances. The estimated pollen accumulation rates of Nothofagus at Ballena for the time between 4400 and 2200 cal. yr BP are similar to values estimated for the Lateglacial at sites within the present Nothofagus deciduous forest (Heusser, 1998; Table 4). This suggests that the size of the present day populations of western Tierra del Fuego within the Magellanic moorland are a good analogue for the Lateglacial Nothofagus populations that may have occurred to the east.

\section{Lateglacial-early Holocene vegetation changes}

Major shifts in the composition of plant communities occurred during the Lateglacial-early Holocene transition throughout the region, as climate warmed. The postglacial steppe and heath vegetation gradually declined with the regional expansion of forest patches. At Gran Campo Nevado mire, about $100 \mathrm{~km}$ to the northwest, there was a main vegetation change towards the development of the Magellanic rain forest at 11,000 cal. yr BP (Fesq-Martin et al., 2004). At the same time, major changes in vegetation composition took place towards the east, at both lowland and high elevation sites (Heusser, 1995, 1998; McCulloch and Davies, 2001; Markgraf and Huber, 2010). Glacier and palaecological evidence indicate the onset of warm interglacial conditions at c. 11,500 cal. yr BP at Torres del Paine, $\sim 50^{\circ} \mathrm{S}$ (Moreno et al., 2009), however slightly earlier (c. 12,000 cal. yr BP) at the Straits of Magellan (McCulloch et al., 2000).

The pollen record from Ballena shows a major change in vegetation composition between 11,000 and $9000 \mathrm{cal}$. yr BP. Changes in the composition of the pollen spectra are marked by the expansion of Nothofagus, most likely Nothofagus antarctica, and the decline of diverse taxa, particularly Lycopodium magellanicum, Gunnera magellanica, Gaultheria/Lebetanthus myrsinites, Empetrum rubrum and Poaceae. During this period, the postglacial heath and grassland mosaic is progressively replaced by woodland-dominated vegetation. These changes are also reflected in the high amount of change in compositional turnover and rate of change.

The regional expansion of Nothofagus occurred in response to the gradual increase in temperature and precipitation that characterised the Lateglacial-Holocene transition. Temperature reconstructions from ice core records in Antarctica show a steady increase after the Antarctic Cold Reversal ( 12,700 yr BP) towards the onset of the Holocene (Stenni et al., 2011), reaching a temperature maximum of $\sim 3^{\circ} \mathrm{C}$ more than present during the early Holocene, between 11,500 and 9000 yr BP (e.g. Verleyen et al., 2011). Increasing rainfall and wind strength after $\sim 12,500$ cal. yr BP, with a maximum between $\sim 12,000$ and $\sim 8500$ cal. yr $\mathrm{BP}$, has been inferred from marine and terrestrial cores along the fjord region of southern Chile (Lamy et al., 2010). On the other hand, increased burning of the vegetation is evident in the palaecological record during the early Holocene, particularly in sites east of the Andes (Huber et al., 2004; Whitlock et al., 2007). Thus, dry conditions must have prevailed there during the onset of the Holocene (Markgraf and Huber, 2010; Pendall et al., 2001).

The proposed maximum precipitation (Lamy et al., 2010) and temperature optimum (Verleyen et al., 2011) of the early Holocene coincide with the maximum extension of Nothofagus woodland around Ballena between 10,000 and 9000 cal. yr BP. Subsequently, Nothofagus woodland decreased and bog plant 
communities became widespread. The partial replacement of the newly established woodland by cushion bog communities may have been caused by a negative effect of the cushion plants on woody seedlings. The cushion bogs formed by Astelia pumila and Donatia fascicularis develop extensive and rigid carpets which may have limited seedling establishment and recruitment of trees. However, the expansion of bog plants was favoured by the prevailing environmental conditions. Simultaneously to the expansion of cushion bogs there is a shift in woodland species composition to Nothofagus betuloides, a more wet-demanding species, and immigration of rainforest elements. At the same time, cushion bog plants expanded at Gran Campo Nevado mire, where the expansion of rain forest taxa (e.g. Drimys winteri) occurred however slightly earlier, at 10,000 cal. yr BP (Fesq-Martin et al., 2004).

The increase in temperature and precipitation that characterised the Lateglacial-Holocene transition should have been adequate to cause an important shift in vegetation composition, as well as the expansion and spread of Nothofagus species. However, it is not until 9000 cal. yr BP that the Magellanic rain forest established and moorland communities expanded through the westernmost region.

\section{Mid- to late-Holocene vegetation and the impact of the Mt Burney 2 volcanic eruption}

The early- to mid-Holocene landscape around Ballena was characterized by a long period of vegetation stability of $c .4000$ years, until about 5200 cal. yr BP when the Mt Burney 2 eruption produced a significant impact on the regional vegetation (FesqMartin et al., 2004; Kilian et al., 2006). The major cause of ecosystem damage (e.g. considerable loss of vegetation cover) has been attributed to intense soil acidification by $\mathrm{SO}_{2}$ released from the tephra, coupled to the low acid-buffering capacity of the soils (Kilian et al., 2006).

A change in vegetation composition around Ballena, as a consequence of volcanic fallout, is recorded between 5200 and 4500 cal. yr BP (pollen zone B-4). These changes are marked by the increase in pollen abundance of Nothofagus, Misodendrum, Pilgerodendron uviferum and the decline of bog communities. Surprisingly, the tephra layer pre-dates the zone boundary by about 250 years. Moreover, changes in the composition of the pollen assemblages are not significant in samples immediately above the tephra layer but in the following two samples, $1 \mathrm{~cm}$ above it. It is likely that during settling the tephra particles sank into the sediment-water interface and underling gyttja, however, forming an undisturbed and compact horizontal layer. Pollen concentration and accumulation rates dropped by a factor of four in the lowermost samples of zone B-4 (Figure 4b), evidencing a significant decline of the vegetation cover around the lake, which is accompanied by the decline in plant diversity (Figure 4a). Low loss-onignition values in the samples at both sides of the B-4 boundary reflect also changes in the catchment hydrology. Noticeable is the large proportion of corroded pollen of Nothofagus and Gunnera magellanica in these two samples, indicating increased erosion. LOI values in the following samples, however, peak up to $75 \%$, suggesting large input of nutrients leached from the surroundings into the lake.

The immediate disturbance of the environment by ash deposition seems to have had a short-term effect. The vegetation recovered within 700 years, at least in terms of species composition and density, as indicated by the re-establishment of pollen taxonomic diversity and PAR values. However the new vegetation structure differed from that before the eruption, clearly illustrated in the PCA plot (Figure 6). The decline of bog communities after the tephra fall coincided with the establishment and expansion of Pilgerodendron uviferum in the surroundings of the lake. Pollen of this tree is present in the record from the early Holocene, with values suggesting its regional presence. As a consequence of the reduction in plant cover after the volcanic eruption, new suitable habitats became available, which must have been rapidly colonized by Pilgerodendron uviferum. Today, Pilgerodendron uviferum occurs in waterlogged, poorly drained and acidic soils (Cruz and Lara, 1981). The increased soil acidification caused by volcanic fallout could have played an important role favouring its expansion and, at the same time, retarding the recovery of the pre-existing bogs communities. With the expansion of Pilgerodendron uviferum, Drimys winteri becomes more frequent and other components of the rain forest are recorded for the first time: Lepidothamnus fonkii, Raukaua laetevirens and Tepualia stipularis.

The observed decrease in the dominance of bog communities and the increase of mixed Nothofagus-Pilgerodendron-Drimys woodland is in line with a reduced precipitation pattern and a progressive cooling inferred by Lamy et al. (2010) for the late Holocene. Although these changes in vegetation composition might have been triggered by a shift in the climate regime, it is likely that the disturbances caused by volcanic fallout on the former system facilitated the establishment and/or expansion of newly arrived species, leading to a new stable system with changed species composition.

The aquatic fern Isoëtes savatieri established in the lake shortly after the tephra deposition, perhaps as a consequence of the tephra-induced changes in the silica budget of the lake. Its expansion occurred however later, at $3500 \mathrm{cal}$. yr BP, coinciding with a changing trend in LOI and magnetic susceptibility values. The increased abundance of Isoëtes savatieri, 1500 years after the tephra deposition, could be associated with the slow release of tephra-derived silica into the system (Telford et al., 2004), as well as to the sustained increase in the input of inorganic material into the lake (Hannon et al., 2003).

Towards the present new taxa appeared: Desfontainia fulgens and Asteraceae liguliflorae, indicating that the immigration of new species is still in progress.

The climate of the area is cold, with excessive rainfall, which might have caused leaching and progressive impoverishment of soils, with consequent impact on terrestrial plant communities. However, the record from Ballena shows no evidence for an increase in bog communities, at the expense of woodland, during the late Holocene, as might have been expected if there had been such impoverishment. Either it has not taken place to any significant extent, or the woodland communities are resistant to it, so far, perhaps because nutrients are locked up in the biomass and recycled rapidly. This is in contrast to the situation in northwestern Europe, where woodland has declined and bog communities have increased during the late Holocene (Bennett et al., 1997). Different tree taxa are involved, human impacts are evident in northwestern Europe, and the pattern of climate change may also have varied between the two regions. Additional work will be needed to determine which of these factors is responsible for the differences in the late-Holocene record.

\section{Conclusions}

(1) The northern coast of Isla Santa Inés was deglaciated by $>16,700$ cal. yr BP. Pioneer vegetation was already established at the onset of sediment deposition in the lake basin. The earliest vegetation succession may have occurred on mountain slopes at times when glaciers were still retreating from the lowlands. A tree-less landscape characterized the western archipelago of Tierra del Fuego for most of the Lateglacial period.

(2) Nothofagus woodland became established in western Tierra del Fuego at 10,500 cal. yr BP, however widespread 
scattered trees may have been present in the region since 14,400 cal. yr BP, indicating that Nothofagus would have spread at low population densities, probably from the northeast. Nothofagus antarctica was likely the earlier colonizing tree in the western islands.

(3) After $9000 \mathrm{cal}$. yr BP moorland communities expanded in the region at the expense of Nothofagus woodland. Simultaneously, woodland composition shifted to a dominance of Nothofagus betuloides, and the Magellanic rain forest became established in the region.

(4) Rapid and drastic vegetation changes occurred at 5200 cal. yr BP as a consequence of volcanic fallout. Most significant changes are marked by the expansion and establishment of Pilgerodendron uviferum in the vicinity of the lake and the development of mixed NothofagusPilgerodendron-Drimys woodland, which persists until the present.

(5) Scattered populations of Nothofagus, as they occur today in westernmost Tierra del Fuego may be a good analogue for the size of Nothofagus populations during the Lateglacial in eastern sites.

(6) Climate, dispersal barriers and/or fire disturbance may have played a role controlling the postglacial spread of Nothofagus. Climate change during the Lateglacial and early Holocene was a prerequisite for the expansion of Nothofagus populations and may have controlled it at many sites in Tierra del Fuego. The delayed arrival at the site, with respect to the Holocene warming, may be due to dispersal barriers and/or fire disturbance at eastern sites, reducing the size of the source populations. The retreat of Nothofagus woodland after 9000 cal. yr BP may be due to competitive interactions with bog communities. Volcanic disturbance had a positive influence on the expansion of Pilgerodendron uviferum and facilitated the development of mixed Nothofagus-PilgerodendronDrimys woodland.

(7) There is no evidence for any tendency for woodland to decrease, and bog communities to increase, during the late Holocene.

\section{Acknowledgments}

We thank Charlie Porter and Camilla Hansen for assistance with fieldwork and Sarah Coulter for discussion of the tephrochronology. Thomas Giesecke drafted Figure 1 and provided critical discussions which improved earlier versions of this text. Two anonymous referees are thanked for their valuable comments on the manuscript. Many colleagues assisted in pollen identification: special thanks are due to María Cristina Tellería, Raquel Piñeiro, Gabriela Giudice and Jacqueline van Leeuwen.

\section{Funding}

This research has been supported during its initial stages by the Swedish Research Council. The work was completed with financial support by the German Research Foundation, DFG, to SLF with a personal grant FO 801/1-1, and with a Royal Society Wolfson Research Merit Award to KDB.

\section{References}

Armesto JJ, Casassa I and Dollenz O (1992) Age structure and dynamics of Patagonian beech forests in Torres del Paine National Park, Chile. Vegetatio 98: 13-22.

Auer V (1933) Verschiebungen der Wald- und Steppengebiete Feuerlands in post-glazialer Zeit. Feuerlands in post-glazialer Zeit. Acta Geographica 5: $1-313$.

Auer V (1958) The Pleistocene of Fuego-Patagonia. Part II. The history of the flora and vegetation. Annales Academiae Scientarum Fennicae. A, III, Geologica Geographica 50: 1-239.
Auer V (1974) The isorhythmicity subsequent to the Fuego-Patagonian and Fennoscandian ocean levels transgressions and regressions of the latest glaciation. The significance of tephrochronology, C-14 dating and micropaleontology for Quaternary research. Annales Academiae Scientarum Fennicae. A, III, Geologica Geographica 115: 1-88.

Auer V, Salmi M and Salminen K (1955) Pollen and spore types of Fuego Patagonia. Annales Academiae Scientarum Fennicae. A, III, Geologica Geographica 43: 1-14.

Bennett KD (1983) Devensian Lateglacial and Flandrian vegetational history at Hockham Mere, Norfolk, England. II. Pollen accumulation rates. New Phytologist 95: 489-504.

Bennett KD (1994) Confidence intervals for age estimates and deposition times in late-Quaternary sediment sequences. The Holocene 4: 337-348.

Bennett KD (1996) Determination of the number of zones in biostratigraphical sequences. New Phytologist 132: 155-170.

Bennett KD (2009) Psimpoll 4.27: C program for plotting pollen diagrams and analyzing pollen data. Available online from Queen's University of Belfast, Department of Archaeology and Palaeoecology. http://www. chrono.qub.ac.uk/psimpoll/psimpoll.html; last accessed May 2011.

Bennett KD and Willis KJ (1995) The role of ecological factors in controlling vegetation dynamics on long temporal scales. Giornale Botanico Italiano 129: $243-254$.

Bennett KD and Willis KJ (2001) Pollen. In: Smol JP, Birks HJB and Last WM (eds) Tracking Environmental Change using Lake Sediments. Volume 3: Terrestrial, Algal, and Siliceous Indicators. Kluwer Academic Publishers, pp. 5-32.

Bennett KD, Bunting MJ and Fossitt JA (1997) Long-term vegetation change in the Western and Northern Isles, Scotland. Botanical Journal of Scotland 49: 127-140.

Bennett KD, Haberle SG and Lumley SH (2000) The Last Glacial-Holocene transition in southern Chile. Science 290: 325-328.

Birks HJB (2007) Estimating the amount of compositional change in lateQuaternary pollen-stratigraphical data. Vegetation History and Archaeobotany 16: 197-202.

Birks HJB and Line JM (1992) The use of rarefaction analysis for estimating palynological richness from Quaternary pollen-analytical data. The Holocene 2: 1-10.

Boros A and Járai-Komlódi M (1975) An Atlas of Recent European Moss Spores. Budapest: Akadémiai Kiadó.

Borrero LA (2008) Early occupations in the southern cone. In: Silverman H and Isbell WH (eds) Handbook of South American Archaeology. Springer, pp. 59-77.

Borromei AM (1995) Análisis polínico de una turbera holocénica en el Valle de Andorra, Tierra del Fuego, Argentina. Revista Chilena de Historia Natural 68: 311-319.

Borromei AM, Coronato A, Franzén LG et al. (2010) Multiproxy record of Holocene paleoenvironmental change, Tierra del Fuego, Argentina. Palaeogeography, Palaeoclimatology, Palaeoecology 286: 1-16.

Borromei AM, Coronato A, Quattrocchio M et al. (2007) Late PleistoceneHolocene environments in Valle Carbajal, Tierra del Fuego, Argentina. Journal of South American Earth Sciences 23: 321-335.

Buck CE, Christen JA and James GN (1999) BCal: An on-line Bayesian radiocarbon calibration tool. Internet Archaeology 7 (http://intarch.ac.uk/ journal/issue 7/buck/).

Coronato A, Meglioli A and Rabassa J (2004) Glaciations in the Magellan Straits and Tierra del Fuego, southernmost South America. In: Ehlers J and Gibbard P (eds) Quaternary Glaciations, Extent and Chronolgy, III. Elsevier, pp. 45-48.

Cruz G and Lara A (1981) Tipificación, cambio de estructura y normas de manejo para Ciprés de las Guaitecas (Pilgerodendron uviferum D. Don Florin) en la Isla Grande de Chiloé. Tesis Ingeniero Forestal. Santiago, Chile. Facultad de Ciencias Agrarias y Veterinarias, Universidad de Chile.

Díaz NI and Smith-Flueck JM (2000) The Patagonian Huemul, a Mysterious Deer on the Brink of Extinction. Buenos Aires: LOLA.

Díaz NI, Prieto A and Bahamonde G (2007) Guanacos tímidos, huemules confiados: el limite occidental de los cazadores terrestres australes. Magallania 35: 133-138.

Erdtman G (1943) An Introduction to Pollen Analysis. Waltham MA: Chronica Botanica Company.

Fesq-Martin M, Friedmann A, Peters M et al. (2004) Late Glacial and Holocene vegetation history of the Magellanic rain forest in southwestern Patagonia. Vegetation History and Archaeobotany 13: 249-255.

Giesecke T and Fontana SL (2008) Revisiting pollen accumulation rates from Swedish lake sediments. The Holocene 18: 293-305.

Giesecke T, Miller PA, Sykes MT et al. (2010) The effect of past changes in inter-annual temperature variability on tree distribution limits. Journal of Biogeography 37: 1394-1405. 
Godley EJ (1960) The botany of southern Chile in relation to New Zealand and the Subantarctic. Proceedings of the Royal Society of London, Series B, Biological Sciences 152: 457-475.

Haberle SG and Bennett KD (2004) Postglacial formation and dynamics of north Patagonian rainforest in the Chonos Archipelago, Southern Chile. Quaternary Science Reviews 23: 2433-2452.

Hannon GE, Bradshaw RHW and Wastegård S (2003) Rapid vegetation change during the early Holocene in the Faroe Islands detected in terrestrial and aquatic ecosystems. Journal of Quaternary Science 18: 615-619.

Heiri O, Lotter AF and Lemcke G (2001) Loss on ignition as a method for estimating organic and carbonate content in sediments: Reproducibility and comparability of results. Journal of Paleolimnology 25: 101-110.

Henríquez JM and Lusk CH (2005) Facilitation of Nothofagus antarctica (Fagaceae) seedlings by the prostrate shrub Empetrum rubrum (Empetraceae) on glacial moraines in Patagonia. Austral Ecology 30: 877-882.

Heusser CJ (1971) Pollen and Spores of Chile. Tucson AZ: The University of Arizona Press.

Heusser CJ (1989) Late Quaternary vegetation and climate of Southern Tierra del Fuego. Quaternary Research 31: 396-406.

Heusser CJ (1990) Lateglacial and Holocene vegetation and climate of Subantarctic South America. Review of Palaeobotany and Palynology 65: 9-15.

Heusser CJ (1993) Lateglacial of southern South America. Quaternary Science Reviews 12: 345-350.

Heusser CJ (1994) Quaternary paleoecology of Fuego-Patagonia. Revista do Instituto Geológico - São Paulo, Brazil 15: 7-26.

Heusser CJ (1995) Three late Quaternary pollen diagrams from Southern Patagonia and their palaeoecological implications. Palaeogeography, Palaeoclimatology, Palaeoecology 118: 1-24.

Heusser CJ (1998) Deglacial paleoclimate of the American sector of the Southern Ocean: Late Glacial-Holocene records from the latitude of Beagle Channel $\left(55^{\circ} \mathrm{S}\right)$, Argentine Tierra del Fuego. Palaeogeography, Palaeoclimatology, Palaeoecology 141: 277-301.

Heusser CJ (2003) Ice Age Southern Andes - A Chronicle of Paleoecological Events. Developments in Quaternary Science 3, Amsterdam: Elsevier.

Heusser CJ and Rabassa J (1987) Cold climatic episode of Younger Dryas age in Tierra del Fuego. Nature 328: 609-611.

Heusser CJ, Heusser LE, Lowell TV et al. (2000) Deglacial palaeoclimate at Puerto del Hambre, subantarctic Patagonia, Chile. Journal of Quaternary Science 15: 101-114.

Heusser CJ, Streeter SS and Stuiver M (1981) Temperature and precipitation record in southern Chile extended to $\sim 43,000$ yr ago. Nature 294: 65-67.

Hill MO and Gauch HG (1980) Detrended correspondence analysis, an improved ordination technique. Vegetatio 42: 47-58.

Huber U, Markgraf V and Schäbitz F (2004) Geographical and temporal trends in Late Quaternary fire histories of Fuego-Patagonia, South America. Quaternary Science Reviews 23: 1079-1097.

Hulton NRJ, Purves RS, McCulloch RD et al. (2002) The Last Glacial Maximum and deglaciation in southern South America. Quaternary Science Reviews 21: 233-241

Kilian R, Biester H, Behrmann J et al. (2006) Millennium-scale volcanic impact on a superhumid and pristine ecosystem. Geology 34: 609-612.

Kilian R, Hohner M, Biester H et al. (2003) Holocene peat and lake sediment

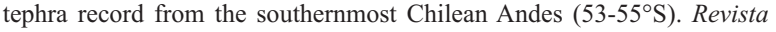
Geológica de Chile 30: 23-37.

Kilian R, Schneider C, Koch J et al. (2007) Palaeoecological constraints on Late Glacial and Holocene ice retreat in the Southern Andes $\left(53^{\circ} \mathrm{S}\right)$. Global and Planetary Change 59: 49-66.

Lamy F, Kilian R, Arz HW et al. (2010) Holocene changes in the position and intensity of the southern westerly wind belt. Nature Geoscience 3: 695-699.

Lliboutry L (1998) Glaciers of Chile and Argentina. In: Williams RS and Ferrigno JG (eds) Satellite Image Atlas of Glaciers of the World: South America. United States Geological Survey Professional Paper 1386I, pp. 109-206.

McCormac G, Hogg AG, Blackwell PG et al. (2004) SHCa104 Southern Hemisphere calibration, 0-11.0 cal kyr BP. Radiocarbon 46: 1087-1092.

McCulloch RD and Davies SJ (2001) Lateglacial and Holocene palaeoenvironmental changes in the central Strait of Magellan, southern Patagonia. Palaeogeography, Palaeoclimatology, Palaeoecology 173: 143-173.

McCulloch RD, Bentley MJ, Purves RS et al. (2000) Climatic inferences from glacial and palaeoecological evidence at the last glacial termination, southern South America. Journal of Quaternary Science 15: 409-417.

McCulloch RD, Fogwill CJ, Sugden DE et al. (2005) Chronology of the last glaciation in central Strait of Magellan and Bahía Inútil, southernmost South America. Geografiska Annaler. A, Physical Geography 87: 289-312.
McQueen DR (1976) The ecology of Nothofagus and associated vegetation in South America. Part I. Vegetation and soils in Southern Patagonia and Tierra del Fuego. Tuatara 22: 38-68.

Markgraf V (1980) New data on the late- and postglacial vegetational history of La Misión, Tierra del Fuego, Argentina. Proceedings IV International Palynological Conference, Lucknow, India 3: 68-74.

Markgraf V (1983) Late and postglacial vegetational and paleoclimatic changes in subantarctic, temperate, and arid environments in Argentina. Palynology 7: 43-70.

Markgraf V (1993a) Paleoenvironments and paleoclimates in Tierra del Fuego and southernmost Patagonia, South America. Palaeogeography, Palaeoclimatology, Palaeoecology 102: 53-68.

Markgraf V (1993b) Younger Dryas in southernmost South America - An update. Quaternary Science Reviews 12: 351-355.

Markgraf V (2001) Interhemispheric Climate Linkages. Academic Press.

Markgraf V and D'Antoni HL (1978) Pollen Flora of Argentina. Tuscon AZ: The University of Arizona.

Markgraf V and Huber UM (2010) Late and postglacial vegetation and fire history in Southern Patagonia and Tierra del Fuego. Palaeogeography, Palaeoclimatology, Palaeoecology 297: 351-366.

Markgraf V and McGlone M (2005) Southern temperate ecosystem responses. In: Lovejoy TE and Hannah L (eds) Climate Change and Biodiversity. Yale University, pp. 142-156.

Markgraf V, McGlone M and Hope G (1995) Neogene paleoenvironmental and paleoclimatic change in southern temperate ecosystems - A southern perspective. Trends in Ecology \& Evolution 10: 143-147.

Mauquoy D, Blaauw M, van Geel B et al. (2004) Late Holocene climatic changes in Tierra del Fuego based on multiproxy analyses of peat deposits. Quaternary Research 61: 148-158.

Molina AM (1978) El género Gunnera en la Argentina y el Uruguay (Gunneraceae). Darwiniana 21: 473-489.

Moore DM (1983) Flora of Tierra del Fuego. Anthony Nelson Ltd.

Morbelli MA (1980) Morfología de las esporas de Pteridophyta presentes en la región fuego-patagónica. República Argentina. Opera Lilloana 28: $1-138$.

Moreno PI, Kaplan MR, François JP et al. (2009) Renewed glacial activity during the Antarctic cold reversal and persistence of cold conditions until $11.5 \mathrm{ka}$ in southwestern Patagonia. Geology 37: 375-378.

Odgaard BV (2007) Reconstructing past biodiversity development. In: Elias SA (ed.) Encyclopedia of Quaternary science. Elsevier, pp. 2508-2514.

Pendall E, Markgraf V, White JWC et al. (2001) Multiproxy record of late Pleistocene-Holocene climate and vegetation changes from a peat bog in Patagonia. Quaternary Research 55: 168-178.

Pisano E (1971) Comunidades vegetales del área del Fiordo Parry, Tierra del Fuego. Anales del Instituto de la Patagonia 2: 93-133.

Pisano E (1977) Fitogeografía de Fuego-Patagonia chilena I. Comunidades vegetales entre las latitudes $52^{\circ}$ y $56^{\circ} \mathrm{S}$. Anales del Instituto de la Patagonia 8: 121-250.

Pisano E (1978) Establecimiento de Nothofagus betuloides (Mirb.) Blume en un valle en proceso de desglaciación. Anales del Instituto de la Patagonia 9: $107-128$.

Pisano E (1983) The magellanic tundra complex. In: Gore AJR (ed.) Ecosystems of The World 4B: Mires, Swamp, Bog, Fen and Moor. Regional Studies. Elsevier, pp. 295-329.

Ponce JF, Borromei AM, Rabassa JO et al. (2011) Late Quaternary palaeoenvironmental change in western Staaten Island $\left(54.5^{\circ} \mathrm{S}, 64^{\circ} \mathrm{W}\right)$, Fuegian Archipelago. Quaternary International 233: 89-100.

Promis A, Cruz G, Reif A et al. (2008) Nothofagus betuloides (Mirb.) Oerst. 1871 (Fagales: Nothofagaceae) forests in southern Patagonia and Tierra del Fuego. Anales del Instituto de la Patagonia 36: 53-67.

Rabassa J, Coronato A, Bujalesky G et al. (2000) Quaternary of Tierra del Fuego, southernmost South America: An updated review. Quaternary International 68-71: 217-240

Rabassa J, Coronato A, Roig C et al. (2005) Los bosques de Tierra del Fuego durante el Cuaternario. In: Arturi MF, Frangi JL and Goya JF (eds) Ecología y Manejo de los Bosques de Argentina. Editorial de la Universidad Nacional de La Plata (EDULP). Available online: http:// www.sedici.unlp.edu.ar/search/request.php?id_document=ARG-UNLPEBook-0000000006.

Recasens C, Ariztegui D, Gebhardt C et al. (2011) New insights into paleoenvironmental changes in Laguna Potrok Aike, southern Patagonia, since the Late Pleistocene: The PASADO multiproxy record. The Holocene (this issue) doi: $10.1177 / 0959683611429833$.

Reimer PJ, Baillie MGL, Bard E et al. (2009) IntCa109 and Marine09 radiocarbon age calibration curves, 0-50,000 years cal BP. Radiocarbon 51: 1111-1150. 
Stenni B, Buiron D, Frezzotti M et al. (2011) Expression of the bipolar sea-saw in Antarctic climate records during the last deglaciation. Nature Geoscience 4: 46-49.

Stern CR (2008) Holocene tephrochronology record of large explosive eruptions in the southernmost Patagonian Andes. Bulletin of Volcanology 70 435-454.

Stockmarr J (1971) Tablets with spores used in absolute pollen analysis. Pollen et Spores 13: 615-621.

Stockmarr J (1972) Determination of spore concentration with an electronic particle counter. Danmarks Geologiske Undersøgelse, Arbog pp. 87-89.

Sweda T (1987) Recent retreat of Soler Glacier, Patagonia as seen from vegetation recovery. Bulletin of Glacier Research 4: 119-124.

Telford RJ, Barker P, Metcalfe S et al. (2004) Lacustrine responses to tephra deposition: Examples from Mexico. Quaternary Science Reviews 23: 2337-2353.

ter Braak CJF (1986) Canonical correspondence analysis: A new eigenvector technique for multivariate direct gradient analysis. Ecology 67: 1167-1179.

ter Braak CJF and Šmilauer P (2002) CANOCO Reference Manual and CanoDraw for Windows User's Guide: Software for Canonical Community Ordination (version 4.5). Ithaca NY: Microcomputer Power.

van Winden J (2006) Diet and habitat of the huemul (Hippocamelus bisulcus) in Bernardo O' Higgins National Park, Chile. MSc Thesis Biology, Utrecht University. NWS-I-2006-15. Available at http://nws.chem.uu.nl/ publica/Studentenrapporten/Studrap2006/I2006-15.pdf
Veblen TT, Hill RS and Read J (1996) The Ecology and Biogeography of Nothofagus Forests. Yale University Press.

Verleyen E, Hodgson DA, Sabbe K et al. (2011) Post-glacial regional climate variability along the East Antarctic coastal margin - Evidence from shallow marine and coastal terrestrial records. Earth Science Reviews 104: 199-212.

Von Post L (1929) Die Zeichenschrift der Pollenstatistik. Geologiska Foereningan i Stockholm. Foerhandlingar (GFF) 51: 543-565.

Whitlock C, Moreno PI and Bartlein P (2007) Climatic controls of Holocene fire patterns in southern South America. Quaternary Research 68: 28-36.

Whittaker RH (1977) Evolution of species diversity in land communities. Evolutionary Biology 10: 1-67.

Wille M, Maidana NI, Schäbitz F et al. (2007) Vegetation and climate dynamics in southern South America: The microfossil record of Laguna Potrok Aike, Santa Cruz, Argentina. Review of Palaeobotany and Palynology 146: 234-246.

Wright HE Jr (1967) A square-rod piston sampler for lake sediments. Journal of Sedimentary Petrology 37: 975-976.

Wright HE Jr (1990) An improved Hongve sampler for surface sediments. Journal of Paleolimnology 2: 91-92.

Young SB (1972) Subantarctic rain forest of Magellanic Chile: Distribution, composition, and age and growth rate studies of common forest trees. Antarctic Research Series 20: 307-322. 